\title{
EVALUASI PENGELOLAAN ORGANISASI NON PROFIT UNTUK MENUNJANG TRANSPARANSI DAN AKUNTABILITAS BAGI DONATUR
}

\author{
Agung Sri Wardani \\ Program Studi Akuntansi Politeknik Ubaya \\ Jalan Ngagel Jaya Selatan 169, Surabaya \\ Bambang Herwanto \\ Program Studi Akuntansi Politeknik Ubaya \\ Jalan Ngagel Jaya Selatan 169, Surabaya \\ Ratnawati Hari Prayitno \\ Program Studi Akuntansi Politeknik Ubaya \\ Jalan Ngagel Jaya Selatan 169, Surabaya
}

\begin{abstract}
Financial statement is one of the essential thing in managing finance in an organization. Both profit oriented organizations and non profit oriented organizations requires relevant, reliable, comparable and understandable information in financial statements presented. Moreover, the non profit organizations, which the largest source of funding is donated from donors, the possibility of fraud becomes bigger. It is usually done by several parties, even by the management itself. Therefore, the diclosure of relevant, reliable, comparable, and understandable financial statements, are necessary done by the non profit organizations. The disclosure of financial statement needs a healthy organization management, good strategic management, finance report based on the accounting standards (PSAK 45) and good technology utilization. The technology utilization by web based financial statement are expected to be faster in presenting the non profit organization financial statement. With the stages of process that are undertaken, hopefully it will increase transparency of accountability for the donors.
\end{abstract}

\begin{abstract}
ABSTRAK
Laporan keuangan merupakan salah satu bagian penting dalam pengelolaan keuangan suatu organisasi. Semua organisasi baik organisasi berorientasi profit maupun non profit, membutuhkan informasi yang relevan, andal, dapat diperbandingkan dan dapat dipahami dalam laporan keuangan yang disajikan. Terlebih lagi organisasi non profit, di mana sumber pendanaan terbesar berupa sumbangan yang berasal dari donatur. Sangat besar kemungkinan terjadi kecurangan dalam organisasi non profit. Kecurangan tersebut biasanya dilakukan
\end{abstract}


oleh beberapa pihak bahkan oleh pihak manajemen sendiri. Untuk itu pengungkapan laporan keuangan yang relevan, andal, dapat diperbandingkan dan dapat dipahami sangat diperlukan dalam organisasi non profit. Pengungkapan laporan keuangan tersebut perlu adanya pengelolaan organisasi yang sehat, manajemen strategi yang baik, pelaporan keuangan yang sesuai dengan standar akuntansi (PSAK 45) dan pemanfaatan teknologi yang baik. Pemanfaatan teknologi dengan pembuatan laporan keuangan berbasis web diharapkan dapat lebih cepat dalam penyajian laporan keuangan organisasi non profit. Dengan tahapan proses yang dilakukan tersebut, diharapkan dapat meningkatkan transparansi dan akuntabilitas bagi donatur.

Keywords: strategic management, non profit organization, PSAK 45, management of web-based financial accounting.

\section{PENDAHULUAN}

Laporan keuangan merupakan salah satu bentuk pertanggungjawaban tehadap aktivitas suatu organsasi, baik organisasi berorientasi profit maupun non profit. Laporan keuangan merupakan hasil dari proses akuntansi yang meliputi proses pencatatan sampai dengan pelaporan dan analisis laporan keuangan. Ikatan Akuntan Indonesia (2012) mendefinisikan laporan keuangan sebagai bagian dari proses pelaporan keuangan, secara umum bertujuan untuk memberikan informasi mengenai posisi keuangan, kinerja, dan arus kas perusahaan yang bermanfaat bagi pengguna laporan untuk membuat keputusan ekonomi serta pertanggungjawaban manajemen atas penggunaan sumber daya yang dipercayakan kepada mereka. Agar dapat memberikan informasi yang berguna, maka laporan keuangan yang disajikan harus memiliki karakteristik yang relevan, andal, dapat dipahami dan dapat dibandingkan.

Informasi yang dilaporkan dalam laporan keuangan tersebut dipergunakan oleh semua pihak baik organisasi profit maupun non profit. Nainggolan
(2012) mengelompokkan organisasi menjadi 3, yaitu: organisasi komersial yang dibiayai oleh laba atau keuntungan dari kegiatannya, organisasi pemerintah yang dibiayai oleh masyarakat melalui pajak atau retribusi dan organisasi nirlaba yang dibiayai masyarakat lewat sumbangan atau donasi.

Dalam pengelolaan suatu organisasi baik organisasi berorientasi profit maupun non profit harus memiliki strategi pengelolaan yang baik, sehingga dapat melakukan prediksi dan proyeksi yang lebih baik di masa depan. Pengelolaan keuangan organisasi non profit juga sangat memerlukan adanya strategi pengelolaan keuangan yang baik dan memadai, mengingat keuangan sangat rentan dilakukan kecurangan oleh berbagai pihak. Sumber dana organisasi non profit yang berasal dari sumbangan atau donasi sangat rentan mengalami kecurangan oleh pengelola atau manajemen sendiri. Kecurangan yang dilakukan oleh manajemen pengelola dapat terjadi pada semua organisasi non profit, termasuk dalam pengelolaan dana gereja sebagai salah satu organisasi non profit. Menurut Kaomaeng (2013) permasalahan terse- 
but biasanya tidak ditangani secara serius oleh para pejabat gereja, bahkan ada kesan ditutup-tutupi dan dibiarkan saja tanpa adanya tindakan yang tegas.

Alasan yang sering dikemukakan karena gereja dianggap sebagai lembaga sosial, sehingga permasalahan tersebut diselesaikan dengan kasih. Ada juga yang mengatakan bahwa masalah keuangan adalah masalah yang sensitif karena itu harus hati-hati dalam menangani kasus ini untuk menghindari dari hal-hal yang akan merusak keutuhan dan kewibawaan gereja.

Untuk itu, pengelolaan organisasi non profit yang tepat sangat diperlukan agar dapat memberikan kepercayaan yang lebih kepada donatur. Salah satu hal yang sangat perlu dilakukan adalah pengungkapan atau disclosure yang wajib dilakukan oleh pengelolaan keuangan itu sendiri. Salah satu cara yang dapat dilakukan adalah mengungkapkan laporan keuangan yang relevan, andal, dapat diperbandingkan dan dapat dipahami.

Pengelolaan keuangan non profit di Indonesia pada dasarnya telah diatur dalam Standar Akuntansi Keuangan, yaitu pada Pernyataan Standar Akuntansi Keuangan/PSAK 45 (Ikatan Akuntan Indonesia, 2012). Namun demikian banyak pengelola organisasi non profit belum memahami PSAK tersebut. Hal lain yang sangat perlu dilakukan dalam pengelolaan keuangan non profit adalah dengan mengikuti perkembangan zaman yang ada saat ini. Perkembangan teknologi informasi yang ada saat ini sangat menunjang dalam pengelolaan keuangan khususnya organisasi non profit. Salah satunya adalah dapat dilakukan dengan membuat aplikasi berbasis web atau cloud untuk menunjang transparansi dan akuntabilitas bagi donatur.
Dengan pengelolaan keuangan yang baik diharapkan dapat memberikan informasi yang berarti kepada pihak donatur. Laporan keuangan yang baik, yaitu relevan, andal, dapat diperbandingkan dan dapat dipahami, diharapkan dapat lebih meningkatkan kepercayaan donatur, dan ke depannya diharapkan semakin banyak pihak donatur yang berkeinginan untuk memberikan sumbangan. Melihat penting dan rawannya kecurangan yang dilakukan dalam pengelolaan keuangan organisasi non profit, maka dalam penulisan ini akan dibahas mengenai manajemen stratejik dalam pengelolaan organisasi non profit, standar akuntansi keuangan yang mengatur organisasi non profit, dan prototipe pengelolaan keuangan organisasi non profit.

\section{Pengungkapan Laporan Keuangan Non Profit}

Pengelolaan organisasi non profit sangatlah berbeda dengan organisasi yang berorientasi profit. Tujuan organisasi nirlaba bukanlah memaksimalkan kekayaan pemegang saham, seperti halnya perusahaan beorientasi profit. Organisasi non profit memiliki cara yang berbeda untuk mengukur kinerja organisasinya. Namun demikian beberapa penelitian menunjukkan bahwa organisasi non profit juga memiliki motivasi dan peluang untuk menyajikan laporan keuangan yang tidak benar kepada donatur dengan menunjukkan kinerja keuangan yang baik. Hal tersebut tentu saja memberikan informasi yang salah dan tidak tepat dalam pelaporan yang dilakukannya.

Penelitian yang dilakukan oleh Kitching (2009) menyebutkan bahwa manajemen cenderung memiliki informasi yang lebih banyak tentang kondisi keuangan organisasi dan informasi 
seluruh program kegiatan yang ada di organisasi nirlaba dibanding dengan pihak luar. Asimetri informasi tersebut dapat menciptakan peluang untuk dilakukan rekayasa (manajemen) terhadap pengungkapan laporan keuangan suatu organisasi. Asimetri informasi lebih besar terjadi pada organisasi non profit daripada organisasi yang berorientasi pada laba. Begitu juga dalam penelitian yang dilakukan oleh Core et al. (2006) dan penelitian yang dilakukan oleh Fama and Jensen (1983a) menyebutkan bahwa donatur mengalami masalah agensi dengan manajemen organisasi non profit, karena mereka tidak memiliki hak untuk pengambilan keputusan penuh dan karena manajemen tidak sepenuhnya menanggung risiko keuangan atau efek kekayaan organisasi dari keputusan yang dibuatnya.

Menurut Fama and Jensen (1983b) dan Aggarwal et al. (2012) menyebutkan seharusnya ada dewan pengawas dalam mengatasi masalah agensi tersebut, yang tujuannya adalah memberikan pengarahan kegiatan eksekutif atas nama pemangku kepentingan. Gambar 1 berikut ini menunjukkan hubungan organisasi non profit dengan beberapa stakeholder.

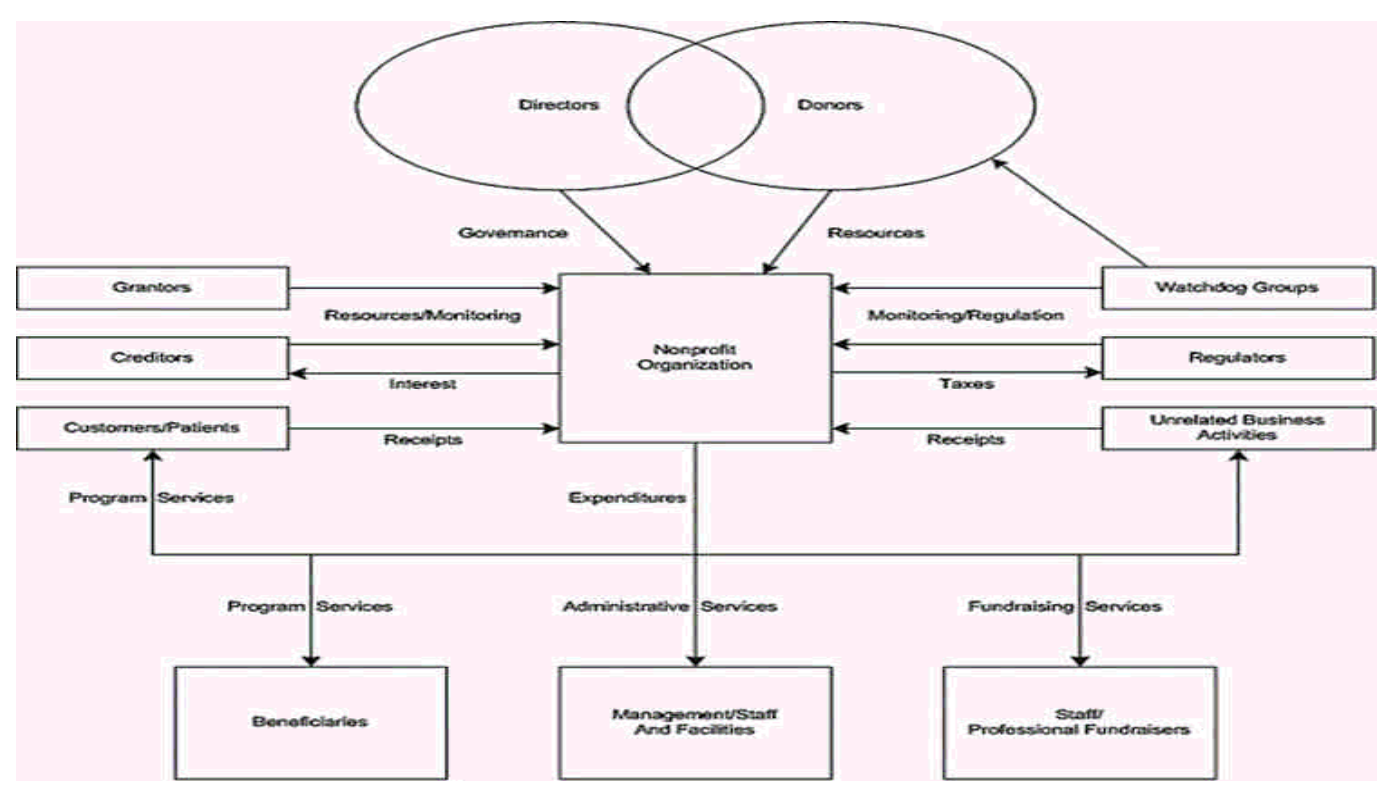

Gambar 1

Hubungan Organisasi Non Profit dengan Stakeholder

Sumber: Hofmann and Dwayne (2013)

Berbagai motivasi yang dilakukan oleh suatu organisasi dalam mengungkapkan laporan keuangan sangatlah berbeda. Dalam penelitian yang dilakukan oleh Hofmann and Dwayne (2013) menyebutkan bahwa berbagai motivasi yang dilakukan suatu organisasi bisa dalam rangka menghindari penurunan pendapatan, smoothing pendapatan dan lain sebagainya. Pada Tabel 1 ditunjukkan perbandingan motivasi dari organisasi profit dan non profit dalam menyusun dan mengungkapkan serta mempublikasikan laporan keuangan organisasinya masingmasing. 
Tabel 1

Perbandingan Praktik Pelaporan dan Motivasi untuk Pengungkapan Manajemen Keuangan

\begin{tabular}{|c|c|c|c|c|}
\hline Type of Entity & Report & $\begin{array}{l}\text { Legally Required } \\
\text { Distribution }\end{array}$ & $\begin{array}{l}\text { Common Voluntary } \\
\text { Distribution }\end{array}$ & $\begin{array}{l}\text { Motivation for Financial } \\
\text { Disclosure Management }\end{array}$ \\
\hline $\begin{array}{l}\text { Publicly traded for- } \\
\text { profit corporation }\end{array}$ & $\begin{array}{l}\text { Audited Financial } \\
\text { Statement } \\
\text { (GAAP) } \\
\text { Tax Return }\end{array}$ & $\begin{array}{l}\text { - SEC } \\
\text { - Shareholders } \\
\text { - General Public (on } \\
\text { Request) } \\
\text { - IRS }\end{array}$ & $\begin{array}{l}\text { - Stock Analysts } \\
\text { - Internet }\end{array}$ & $\begin{array}{l}\text { - Smooth Earning } \\
\text { - Avoid earning decreases or } \\
\text { losses } \\
\text { - Meet analysts forecasts } \\
\text { - Avoid violating debt } \\
\text { covenants } \\
\text { - Maximize managerial } \\
\text { compensation } \\
\text { - Minimize tax liability }\end{array}$ \\
\hline Nonprofit cahrity & $\begin{array}{l}\text { Audited Financial } \\
\text { Statement } \\
\text { (GAAP) } \\
\text { Tax Returns (IRS } \\
\text { Forms 990, 990T, } \\
\text { and 990-PF) }\end{array}$ & $\begin{array}{l}\text { - Certain State } \\
\text { Deparment of } \\
\text { revenue } \\
\text { - Grant-Making } \\
\text { agencies } \\
\text { - IRS } \\
\text { - General Public (on } \\
\text { request) }\end{array}$ & $\begin{array}{l}\text { - Major donors } \\
\text { - Charity watch-dog } \\
\text { groups } \\
\text { - Internet } \\
\text { - Major donors } \\
\text { - Charity watch-dog } \\
\text { groups } \\
\text { - Internet }\end{array}$ & $\begin{array}{l}\text { - Protect tax-exempt status } \\
\text { - Meet grand criteria } \\
\text { - Avoid political costs } \\
\text { - Attact donations } \\
\text { - Improve watchdog ratins } \\
\text { - Enhance managerial/firm } \\
\text { reputation } \\
\text { - Increase managerial } \\
\text { compensation } \\
\text { - Minimize tax on unrelated } \\
\text { business activity } \\
\text { - Minimize taxes on } \\
\text { undistributed income and net } \\
\text { investment income (private } \\
\text { non-operating foundations) }\end{array}$ \\
\hline $\begin{array}{l}\text { Non-charitable non- } \\
\text { profit }\end{array}$ & $\begin{array}{l}\text { Audited Financial } \\
\text { Statement } \\
\text { (GAAP) and IRS } \\
\text { Form } 990 \\
\text { Tax Returns (IRS } \\
\text { Forms 990, 990T, } \\
\text { and } 990-\mathrm{PF}\end{array}$ & $\begin{array}{l}\text { - Certain State } \\
\text { Deparment of } \\
\text { revenue } \\
\text { - IRS } \\
\text { General Public (on } \\
\text { request) }\end{array}$ & $\begin{array}{l}\text { - Members } \\
\text { - Internet }\end{array}$ & $\begin{array}{l}\text { - Enhance managerial } \\
\text { reputation } \\
\text { - Increase managerial } \\
\text { compensation } \\
\text { - Meet state regulatory } \\
\text { standards } \\
\text { - Minimize tax on unrelated } \\
\text { business activity }\end{array}$ \\
\hline
\end{tabular}

Sumber: Hofmann and Dwayne (2013)

\section{Manajemen Strategik Organisasi Non Profit}

Menurut Sutomo (2007) manajemen stratejik organisasi non profit yang baik dapat dilakukan melalui 4 tahapan yang meliputi:

a. Analisis Strategi.

Analisis Strategis bertujuan menyediakan informasi tentang kekuatan, kelemahan, peluang dan ancaman organisasi. Analisis strategi yang dilakukan meliputi:

1. Analisis lingkungan internal. Analisis lingkungan internal bertujuan mendapatkan informasi tentang kekuatan (strengths) dan kelemahan (weaknesses) organisasi yang berkaitan dengan sumber daya (tenaga, sistem/ struktur, peralatan, keuangan) produk/pelayanan, pelanggan/ klien, fasilitas, sistem, prosedur.

2. Analisis Lingkungan Eksternal. Analisis lingkungan eksternal bertujuan mendapatkan informasi tentang peluang (opportunities) dan ancaman (threats) yang mempengaruhi perjalanan organisasi dalam mencapai tujuannya. Hal tersebut mencakup faktor politik, ekonomi, sosial dan teknologi yang berkaitan dengan 
perubahan yang terjadi selama 1-5 tahun mendatang. Melalui analisis metode prediksi dan proyeksi dapat diidentifikasi berbagai isu penting yang harus diselesaikan melalui berbagai strategi. Hal tersebut menjadi arahan untuk merumuskan visi, misi, nilai dan kemampuan unggul serta formulasi untuk mencapai suatu tujuan.

b. Formulasi Strategi.

Formulasi strategi merupakan proses menyiapkan strategi untuk mencapai tujuan. Menurut Kearns (2000) strategi dibagi menjadi 3 bagian, yaitu:

1. Strategi Umum.

Strategi umum adalah keputusan pimpinan yang menentukan ruang lingkup dan arahan seluruh organisasi.

2. Strategi Unit.

Strategi unit merupakan keputusan pimpinan unit dalam menentukan arahan dan pedoman pelaksanaan unit untuk mencapai tujuan. Strategi unit berfokus pada pengembangan strategi di tiap unit organisasi, sehingga mampu berkompetisi dan berhasil.

3. Strategi Fungsional.

Strategi fungsional menjalankan strategi umum dan unit. Strategi fungsional bersifat lebih operasional untuk mengatasi isu terkait dengan pelayanan, kemampuan tenaga, riset dan lainnya.

c. Implementasi Strategi.

Implementasi strategi merupakan tahapan untuk penyusunan plan of action untuk melaksanakan strategi. Silbiger (1998) menjelaskan bahwa strategi yang telah dipilih harus diterjemahkan menjadi progam implementasi. Banyak organisasi nir- laba yang menyusun strategi dalam dokumentasi yang menarik, tetapi tidak menjadi kenyataan praktis. Berdasarkan besar masalah dan waktu penyelesaian, pendekatan implementasi stratejik meliputi:

1. Intervensi Rutin.

Intevensi rutin dilakukan ketika organisasi menghadapi masalah kecil dan waktu yang tidak mendesak.

2. Intervensi Manajerial.

Terjadi ketika organisasi menghadapi masalah kecil, tetapi dalam waktu yang mendesak

3. Intervensi Berurutan.

Intervensi ini dilakukan pada saat perusahaan menghadapi masalah besar yang menyangkut berbagai aspek. Pimpinan melakukan intervensi berurutan untuk mengatasi masalah dalam waktu beberapa tahun.

4. Intervensi Komplek.

Jika dalam waktu terbatas dan mendesak perlu dilakukan intervensi komplek melalui koordinasi, kerjasama, kelompok kerja atau mekanisme lain untuk mengatasi masalah secara bersama.

d. Evaluasi Strategi.

Evaluasi strategi mempelajari kemajuan pelaksanaan strategi, mengevalusi kinerja organisasi dalam mencapai tujuan dan memperbaiki strategi/program di masa yang akan datang.

\section{Standar Akuntansi Pengelolaan Keuangan Organisasi Non Profit \\ Pengelolaan keuangan organisasi non profit telah diatur dalam PSAK 45 (Ikatan Akuntan Indonesia, 2012) yang menyebutkan bahwa karakteristik or- ganisasi non profit adalah:}


a. Sumber daya entitas nirlaba berasal dari para penyumbang yang tidak mengharapkan pembayaran kembali atau manfaat ekonomi yang sebanding dengan jumlah sumber daya yang diberikan.

b. Menghasilkan barang dan/atau jasa tanpa bertujuan memupuk laba, dan jika entitas nirlaba menghasilkan laba, maka jumlahnya tidak dibagikan kepada para pendiri atau pemilik entitas nirlaba tersebut.

c. Tidak ada kepemilikan seperti lazimnya pada entitas bisnis, dalam arti bahwa kepemilikan dalam entitas nirlaba tidak dapat dijual, dialihkan, atau ditebus kembali, atau kepemilikan tersebut tidak mencerminkan proporsi pembagian sumber daya entitas nirlaba pada saat likuidasi atau pembubaran entitas nirlaba.

Tujuan utama laporan keuangan menurut PSAK 45 (Ikatan Akuntan Indonesia, 2012) adalah menyediakan informasi yang relevan untuk memenuhi kepentingan para penyumbang, anggota entitas nirlaba, kreditor, dan pihak lain yang menyediakan sumber daya bagi entitas nirlaba. Pihak pengguna laporan keuangan entitas nirlaba memiliki kepentingan bersama dalam rangka menilai:

a. Jasa yang diberikan oleh entitas nirlaba dan kemampuannya untuk terus memberikan jasa tersebut

b. Cara manajer melaksanakan tanggung jawabnya dan aspek lain dari kinerja mereka.

Pengelolaan akuntansi yang baik dilakukan melalui berberapa tahapan, yaitu: (1) pencatatan; (2) penggolongan; (3) peringkasan (4) pelaporan; (5) penganalisisan data keuangan. Menurut Kieso et al. (2014) siklus akuntansi meliputi:

a. Kegiatan mengidentifikasi dan mengukur transaksi dan peristiwa lainnya.

b. Kegiatan penjurnalan.

c. Kegiatan mem-posting.

d. Kegiatan menyusun neraca saldo yang belum disesuaikan.

e. Kegiatan membuat jurnal penyesuaian.

f. Kegiatan menyusun neraca saldo telah disesuaikan.

g. Kegiatan menyusun Laporan Keuangan.

h. Kegiatan membuat jurnal penutup.

Tahapan siklus akuntansi seperti terlihat pada bagan di Gambar 2.

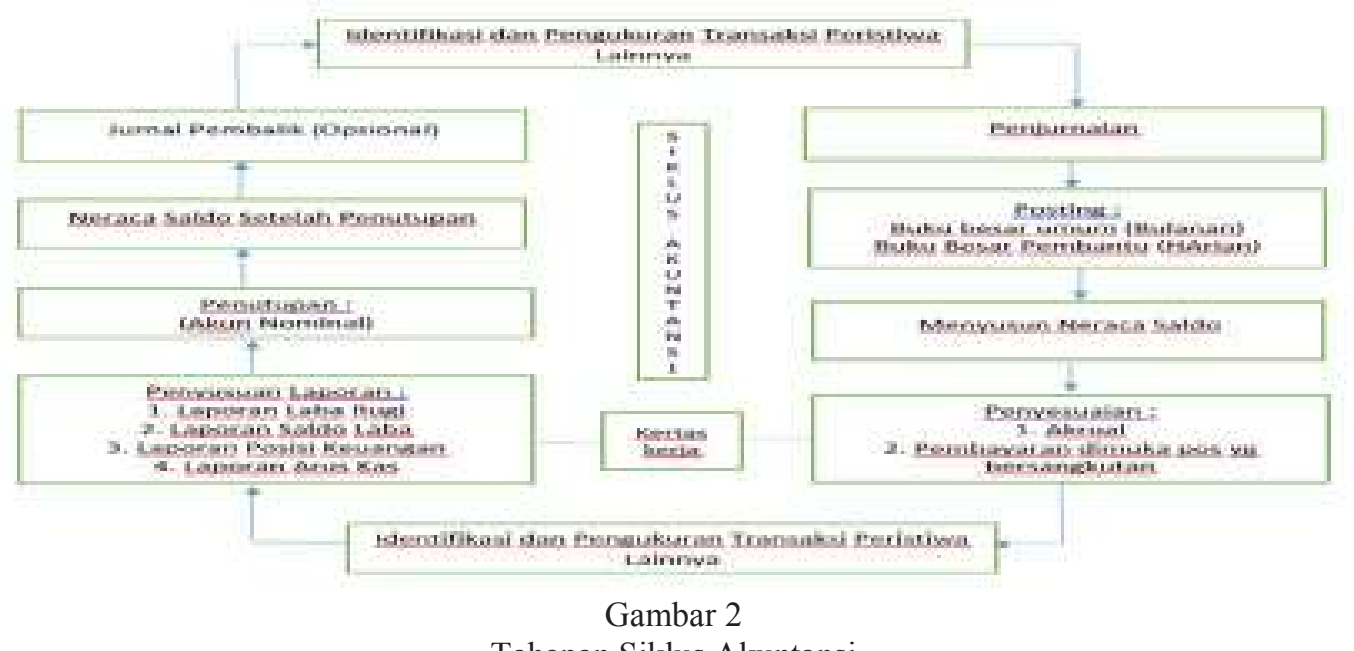

Tahapan Siklus Akuntansi

Sumber: Kieso et al. (2014) 
Laporan keuangan yang harus disajikan oleh organisasi non profit menurut PSAK 45 (Ikatan Akuntan Indonesia, 2012) adalah sebagai berikut:

a. Laporan Posisi Keuangan.

Tujuan laporan posisi keuangan adalah untuk menyediakan informasi mengenai aset, liabilitas, serta aset neto dan informasi mengenai hubungan di antara unsur-unsur tersebut pada waktu tertentu. Informasi dalam laporan posisi keuangan yang digunakan bersama pengungkapan, dan informasi dalam laporan keuangan lainnya dapat membantu para penyumbang, anggota entitas nirlaba, kreditor, dan pihak-pihak lain untuk menilai: (a) kemampuan entitas nirlaba untuk memberikan jasa secara berkelanjutan; dan (b) likuiditas, fleksibilitas keuangan, kemampuan untuk memenuhi kewajibannya, dan kebutuhan pendanaan eksternal. Contoh laporan posisi keuangan sesuai dengan PSAK 45 (Ikatan Akuntan Indonesia, 2012) seperti terlihat pada Tabel 2.

Tabel 2

Contoh Laporan Posisi Keuangan Organisasi Nirlaba

\begin{tabular}{|c|c|c|}
\hline \multicolumn{3}{|c|}{$\begin{array}{l}\text { Entitas Nirlaba } \\
\begin{array}{l}\text { Laporan Posisi Keuangan } \\
31 \text { Desember } 20 \times 2 \text { dan } 20 \times 1\end{array} \\
\text { (dalam jutaan) }\end{array}$} \\
\hline & $20 \times 2$ & $20 \times 1$ \\
\hline \multicolumn{3}{|l|}{ Aset: } \\
\hline Kas dan Setara Kas & $\mathrm{xx \textrm {x }}$ & $\operatorname{sox}$ \\
\hline Riutang bunga & $\operatorname{xxs}$ & $\mathrm{xxx}$ \\
\hline Persodiaan den biaya dibayar dimulca & $\mathrm{xosx}$ & $\operatorname{xocx}$ \\
\hline Prutang Lain Lain & $\operatorname{socx}$ & $\operatorname{cosx}$ \\
\hline Investasi Lancar & $\mathbf{x x x}$ & $\operatorname{xxx}$ \\
\hline Properti Investasi & $\mathrm{xxx}$ & $\operatorname{xxx}$ \\
\hline Asct Tetap & $\mathrm{xox}$ & $\operatorname{xocx}$ \\
\hline Investasi Janska Paniang & $\mathrm{xxx}$ & $\operatorname{xxc}$ \\
\hline Jumlah Aset : & $\mathrm{xxx}$ & $x \times x$ \\
\hline \multicolumn{3}{|l|}{ Liabilitas dan Aset Nete : } \\
\hline Utamg Dagang & $x \times x$ & $x \times x$ \\
\hline $\begin{array}{l}\text { Penclapatan Diterima Dimuka Yang Dapat } \\
\text { Dikembalikan }\end{array}$ & $\mathbf{x x x}$ & $x \times x$ \\
\hline Itang Lain fain & $x \times x$ & $\mathbf{x \times x}$ \\
\hline Kewauban Tahmunan & $\mathrm{x} \times \mathrm{x}$ & $x \times x$ \\
\hline Ulamy Jangku Panjamg & $x \times x$ & $x \times x$ \\
\hline Jumblah I. iahilitas & $\mathbf{x x x}$ & $\mathrm{x} \times \mathbf{x}$ \\
\hline \multicolumn{3}{|l|}{ Aset Neto: } \\
\hline Tidak Terikat & $\mathbf{x x x}$ & $\mathrm{xxx}$ \\
\hline Terikat temporer & $\mathrm{xexx}$ & $\operatorname{xoxx}$ \\
\hline Terikat Permanen & $\operatorname{sxx}$ & $\operatorname{xox}$ \\
\hline Jumlah Aset Neto & $\operatorname{sxx}$ & $\mathrm{xxx}$ \\
\hline Jumlab I Iabilitas dan Aset Neto & $\mathrm{xxOx}$ & $\mathbf{x x x}$ \\
\hline
\end{tabular}

Sumber: Ikatan Akuntan Indonesia (2012) 
Akun-akun yang digunakan dalam laporan posisi keuangan menurut Bastian (2005) adalah sebagai berikut:

- Aset/aktiva adalah sumber daya yang dikuasai oleh entitas atau lembaga sebagai akibat dari peristiwa masa lalu dan sumber manfaat ekonomi di masa yang diharapkan akan diperoleh entitas tersebut.

- Liabilitas/utang adalah kewajiban masa kini yang timbul dari peristiwa masa lalu, yang penyelesaiannya akan mengakibatkan arus keluar dari sumber daya entitas yang mengandung manfaat ekonomi.

- Ekuitas/modal adalah hak residual atas aktiva entitas setelah dikurangi semua liabilitas/utang, misalnya (1) setoran modal dari entitas; (2) saldo surplus/defisit; (3) dana cadangan (disesuaikan dengan kebutuhan organisasi yang ada).

- Aset neto adalah kas atau aset lain yang dibatasi penggunaannya oleh pemberi sumber daya yang tidak mengharapkan pembayaran kembali.

b. Laporan Aktivitas.

Laporan aktivitas adalah laporan yang berisikan mengenai aktivitas entitas non profit secara keseluruhan dan menyajikan perubahan aset neto dalam suatu periode. Menurut PSAK 45 (Ikatan Akuntan Indonesia, 2012) informasi dalam laporan aktivitas yang digunakan bersama dengan pengungkapan informasi dalam laporan keuangan lainnya, membantu para penyumbang, anggota entitas nirlaba, kreditur dan pihak lainnya untuk: (a) mengevaluasi kinerja dalam suatu periode; (b) menilai upaya, kemampuan, dan kesinambungan entitas nirlaba dalam memberikan jasa; dan (c) menilai pelaksanaan tanggung jawab dan kinerja manajer. Akun-akun yang digunakan dalam laporan aktivitas menurut Bastian (2005) adalah sebagai berikut:

- Pendapatan yaitu arus masuk atau peningkatan lain aktiva sebuah entitas atau pelunasan piutang (atau kombinasi dari keduanya) dari pemberian jasa, atau aktivitas lainnya yang merupakan kegiatan utama dan masih berlangsung dari entitas tersebut.

- Biaya adalah arus kas keluar atau penggunaan lain suatu aktiva atau timbulnya utang (atau kombinasi keduanya) dari pemberian jasa, atau pelaksanaan aktivitas lain yang merupakan kegiatan utama dan masih berlangsung dari entitas tersebut.

- Surplus adalah kenaikan ekuitas dari transaksi-transaksi tambahan atau insidentil suatu entitas dan dari semua transaksi lainnya atau kejadian serta keadaan lain yang mempengaruhi entitas tersebut, kecuali yang berasal dari pendapatan atau investasi oleh suatu entitas.

- Defisit adalah penurunan ekuitas dari transaksi-transaksi tambahan atau insidentil suatu entitas dan dari semua transaksi lainnya atau kejadian serta keadaan lain yang mempengaruhi entitas tersebut, kecuali yang berasal dari pendapatan atau investasi oleh suatu entitas.

Contoh laporan aktivitas sesuai PSAK 45 (Ikatan Akuntan Indonesia, 2012) seperti pada Tabel 3. 
Tabel 3

Contoh Laporan Aktivitas Organisasi Nirlaba

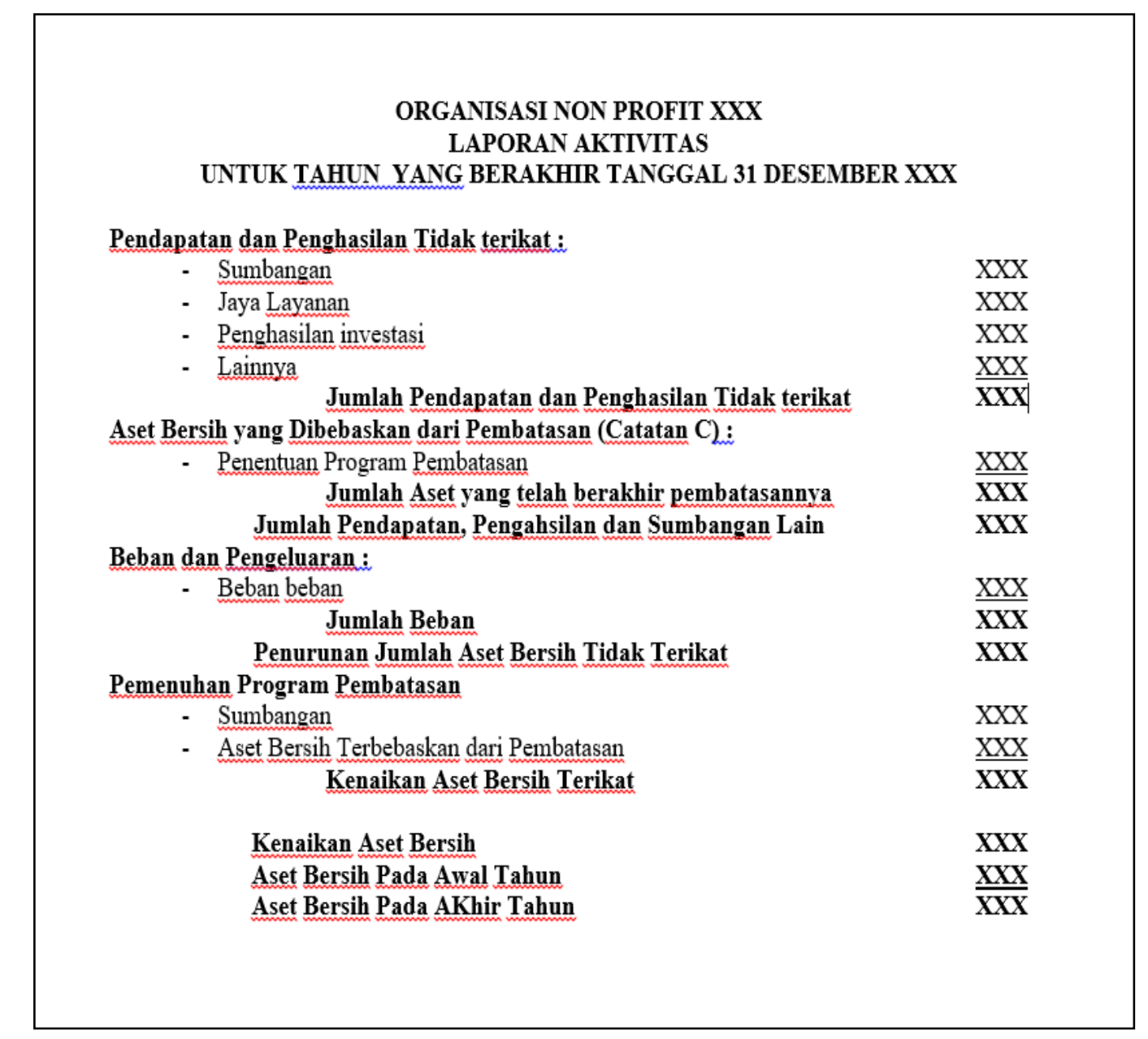

Sumber: Ikatan Akuntan Indonesia (2012)

c. Laporan Arus Kas.

Laporan arus kas merupakan laporan yang menyajikan informasi mengenai penerimaan dan pengeluaran kas dalam suatu periode tertentu. Akun-akun yang digunakan dalam laporan arus kas menurut Bastian (2005) adalah sebagai berikut:

- Arus kas dari aktivitas operasi.

Arus kas masuk dari aktivitas operasi, meliputi: penurunan aktiva lancar dan non kas serta kenaikan utang jangka pendek.
Sedangkan arus kas keluar dari aktivitas operasi meliputi: kenaikan aktiva lancar dan penurunan utang jangka pendek.

- Arus kas dari aktivitas investasi. Arus kas masuk dari aktivitas investasi, meliputi: penurunan investasi jangka panjang dan penurunan aktiva tetap. Sedangkan arus kas keluar dari aktivitas investasi meliputi: kenaikan investasi jangka panjang dan kenaikan aktiva tetap. 
- Arus kas dari aktivitas pembiayaan.

Arus kas masuk dari aktivitas pembiayaan, meliputi: kenaikan utang jangka panjang, kenaikan dana ekuitas, kenaikan dana cadangan. Sedangkan arus kas keluar dari aktivitas pembiayaan meliputi: penurunan utang jangka panjang, penurunan dana ekuitas, penurunan dana cadangan.

Contoh laporan arus kas organisasi non-profit seperti terlihat pada Tabel 4.

Tabel 4

Contoh Laporan Arus Kas Organisasi Nirlaba

\section{ORGANISASI NON PROFIT XXX \\ LAPORAN ARUS KAS \\ UNTUK TAHUN YANG BERAKHIR TANGGAL 31 DESEMBER XXX}

Arus Kas dari Aktivitas Operasional:

Kas dari pendapatan jasa $\quad$ XXX

Kas dari sumbangan $\quad$ XXX

Penerimaan lain lain $\quad$ XXX

Bunga dan deviden yang diterima $\quad \mathrm{XXX}$

Bunga yang dibayarkan $\quad$ (XXX)

Hutang lain yang harus dilunasi

Kas bersih yang diterima (digunakan) untuk aktivitas operasional $\quad$ XXX

Arus Kas dari Aktivitas Investasi:

Pembelian peralatan $\quad$ XXX

Pembelian investasi XXX

Penerimaan dari penjualan investasi $\quad \mathrm{XXX}$

Ganti rugi asuransi kebakaran $\quad$ XXX

Kas bersih yang diterima (digunakan) untuk aktivitas investasi $\quad \underline{\mathrm{XXX}}$

Arus Kas dari Aktivitas Pendanaan :

Penerimaan dari kontribusi:

Investasi bangunan $\quad$ XXX

Investasi perjanjian tahunan $\quad \mathrm{XXX}$

Investasi endowment $\quad \mathrm{XXX}$

Aktivitas pendanaan lainnya:

Bunga dan deviden terbatas untuk reinvestasi $\quad$ XXX

Pembayaran kewaiban tahunan $\quad(X X X)$

Pembayarn utang wesel $\quad$ (XXX)

Pembayaran utang jangka panjang $\quad$ (XXX)

Kas bersih yang diterima (digunakan) untuk aktivitas Pendanaan $\quad$ XXX

Kenaikan (penurunan) bersih dalam kas dan setara kas $\quad$ XXX

Kas dan setara kas pada awal tahun $\quad \underline{\mathbf{X X X}}$

Kas dan setara kas pada akhir tahun $\quad \underline{\mathrm{XXX}}$

Sumber: Ikatan Akuntan Indonesia (2012) 


\section{Pengelolaan Keuangan Organisasi Non Profit Berbasis Web}

Perkembangan teknologi saat ini memberikan pengaruh yang sangat besar bagi kehidupan manusia. Dengan adanya teknologi yang lebih baik diharapkan dapat mempercepat proses penyusunan laporan keuangan, memperkecil kemungkinan kesalahan yang dilakukan oleh manusia. Dengan adanya sistem informasi yang terkomputerisasi, maka proses pengelolaan suatu organisasi menjadi lebih baik lagi. Begitu juga dengan organisasi non profit, pengelolaan organisasi yang terkomputerisasi diharapkan dapat mengurangi terjadi kecurangan dalam suatu organisasi.

Sistem informasi terkomputerisasi menurut Stair and Reynolds (2014) adalah pengorganisasian data dalam suatu hirarki yang dimulai dari bagian terkecil dari suatu data yang disebut karakter, field/atribut, record, file sampai menjadi sebuah basis data (database). Dalam sistem basis data tersebut, berbagai program berinteraksi pada sekumpulan data yang berelasi, yang memiliki kemmapuan untuk berbagi data dan informasi pada beberapa program aplikasi. Menurut Schekkerman (2009) dalam melakukan desain perlu adanya suatu arsitektur enterprise (EA). Dengan menggunakan EA, maka organiasi dapat mengidentifikasi kebutuhan informasi suatu sistem untuk mendukung proses bisnis dan meyakinkan keselarasan dengan kebutuhan organisasi dan fungsi dari teknologi informasi (Pereira and Sousa, 2005).

Delima dan Kristanti (2016) menjelaskan bahwa EA dikembangkan atas dasar adanya kebutuhan untuk dapat mengambil kerangka kerja arsitektur enterprise dalam suatu organisasi yang mengizinkan organisasi untuk mendeskripsikan perusahaan dengan mengambil dan menghubungkan bisnis, aplikasi, informasi dan teknologi. Gambar praktik nyata yang menunjukkan pengelompokkan elemenelemen ke dalam layer arsitektur dengan ketergantungan yang dimiliki terlihat pada Gambar 3.

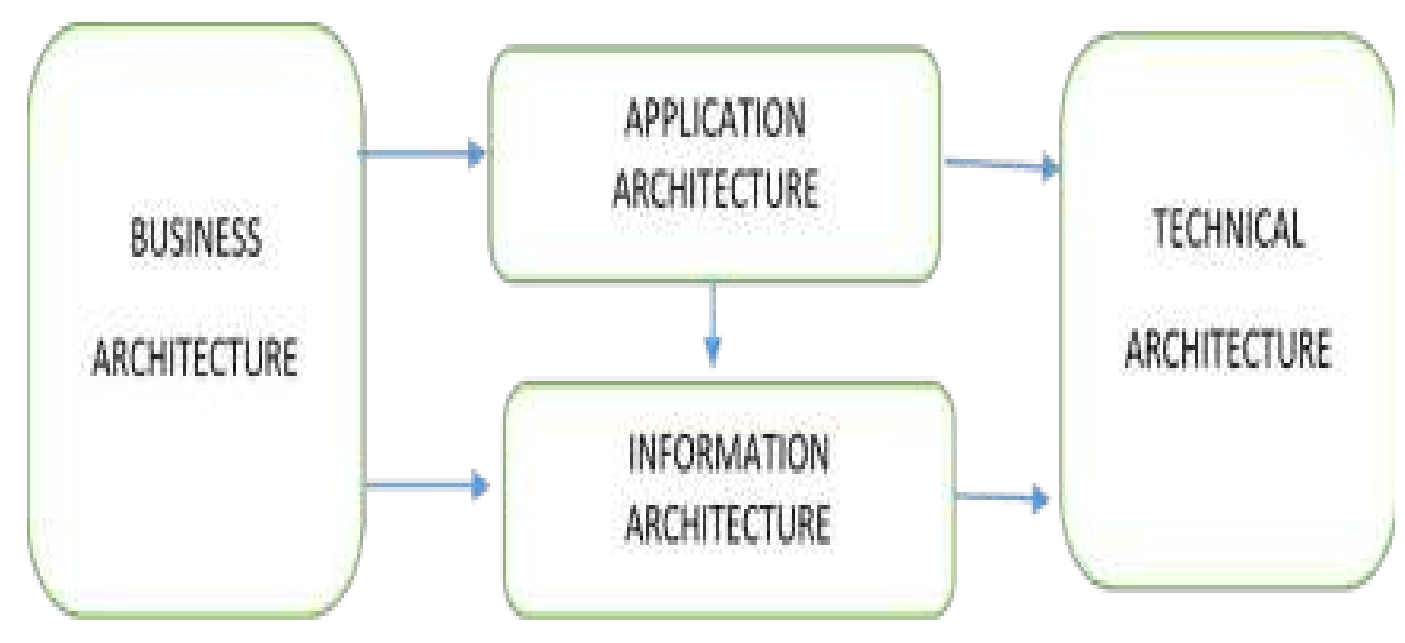

Gambar 3

Layer Arsitektur Entreprise

Sumber: Delima dan Kristanti (2016) 
Menurut Delima dan Kristanti (2016) penggunaan EA didasarkan pada kondisi bahwa sebuah arsitektur teknologi informasi melingkupi sistem informasi dan aplikasi yang ditemukan di dalam unit bisnis spesifik. Dari beberapa perusahaan dan dari berbagai skala, metode ini memungkinkan untuk berdiri secara nyata. Untuk perusahaan yang skala besar kompleksitas dari sistem sangat mempengaruhi sistem informasi yang akan dibangun. Oleh karena itu, arsitektur enterprise harus distandardisasi dan terintegrasi untuk semua level perusahaan. Tanpa standardisasi dan integrasi, perusahaan ataupun suatu organisasi akan menciptakan kegagalannya sendiri (Stenzel, 2007).

Perkembangan teknologi internet saat ini sangat mendukung dalam pe- ngelolaan organisasi. Untuk itu pengelolaan atau pengembangan sistem komputerisasi berbasis web, sangatlah diperlukan. Tujuan dibuatnya sistem informasi berbasis web adalah agar para donatur dapat dengan mudah melakukan akses secara online dan dapat memantau perkembangan organisasi non profit menjadi lebih baik lagi. Menurut Delima dan Kristanti (2016) dalam pengembangan sistem komputerisasi berbasis web terdapat beberapa komponen utama yaitu personal computer untuk pengguna, koneksi internet, web server, web application, dan databases server. Berikut adalah rancangan sistem informasi berbasis web dari Delima dan Kristanti (2016) seperti terlihat pada Gambar 4.

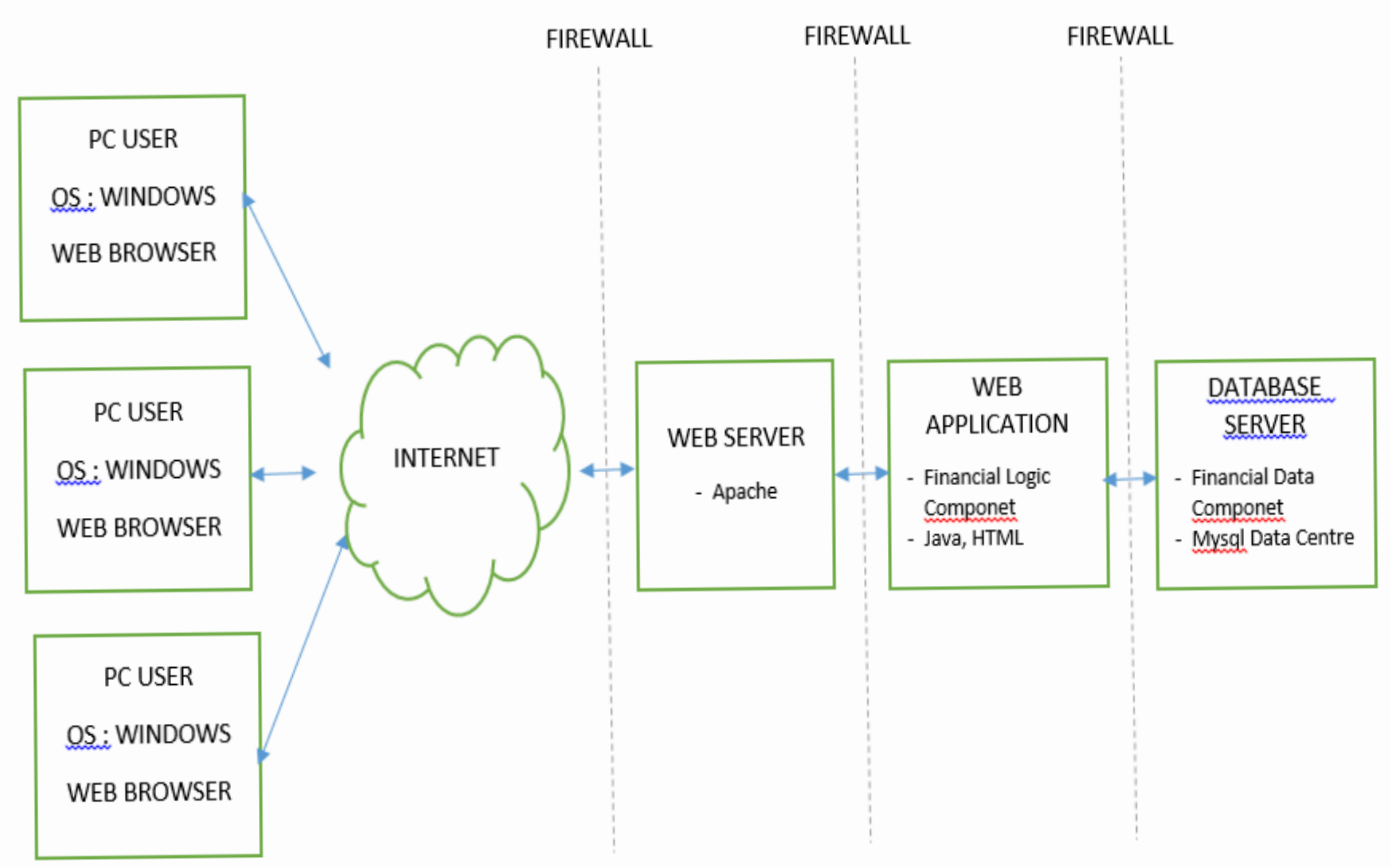

Gambar 4

Rancangan Arsitektur Sistem Informasi Keuangan Berbasis Web

Sumber: Delima dan Kristanti (2016) 


\section{SIMPULAN}

Pengelolaan organisasi non profit memiliki seni yang berbeda dengan mengelola organisasi berorientasi profit. Dalam organisasi non profit, kemungkinan terjadi asimetri informasi lebih besar dibandingkan dengan organisasi berorientasi profit.

Adanya asimetri informasi dapat memberikan peluang yang lebih besar terjadinya kecurangan atau fraud, terutama di dalam penyajian laporan keuangan. Hal ini disebabkan ada berbagai motivasi dari manajemen pengelola organisasi dalam melakukan pengungkapan laporan keuangan.

Untuk dapat menyajikan laporan keuangan yang relevan, andal, dapat diperbandingkan dan dapat dipahami, maka perlu adanya manajemen strategi yang meliputi 4 tahapan, yaitu: (1) analisis strategi; (2) formulasi strategi; (3) implementasi strategi; dan (4) evaluasi strategi.

Selain itu dengan adanya perkembangan teknologi saat ini memberikan pengaruh yang sangat besar bagi kehidupan manusia. Adanya teknologi yang lebih baik diharapkan dapat mempercepat proses penyusunan laporan keuangan, dan dapat memperkecil kemungkinan kesalahan yang dilakukan oleh manusia. Dengan adanya sistem informasi yang terkomputerisasi, maka proses pengelolaan suatu organisasi non profit menjadi lebih baik lagi dan dapat mengurangi terjadi kecurangan.

\section{SARAN}

Agar pihak penyandang dana (donatur) dapat mempercayai dana yang dialokasikannya kepada organisasi non profit, maka pengelola organisasi non profit harus dapat menyampaikan laporan, khususnya laporan keuangan kepada panyandang dana secara tepat waktu dan akurat. Laporan keuangan yang disusun oleh organisasi non profit harus mengacu pada PSAK 45 serta harus memberikan seluruh pengungkapan atau disclosure yang wajib dilakukan oleh pengelola organisasi non profit.
Perkembangan teknologi informasi dan komunikasi yang sangat pesat harus menjadi perhatian pengelola organisasi non profit agar dapat memanfaatkannya secara maksimal dalam seluruh aktivitas organisasi non profit, termasuk penyusunan laporan keuangan berbasis web. Pemanfaatan teknologi informasi diharapkan dapat mempercepat proses penyusunan laporan keuangan, dan dapat memperkecil kemungkinan kesalahan yang dilakukan oleh manusia serta diharapkan akan memperkecil peluang terjadinya kecurangan.

\section{DAFTAR KEPUSTAKAAN}

Aggarwal, Rajesh K., Mark E. Evans and Dhananjay Nanda, 2012, Nonprofit Boards: Size, Performance and Managerial Incentives, Journal of Accounting and Economics, page 466487.

Bastian, Indra, 2009, Akuntansi Pendidikan, Erlangga, Jakarta.

Carla Marques Pereira and Pedro Sousa, 2005, Enterprise architecture: business and IT alignment, In: Proceedings of 2005 ACM Symposium on Applied Computing, Santa Fe, New Mexico, page 1344-1345.

Core, John E., Wayne R. Guay and Rodrigo S. Verdi, 2006, Agency Problems of Excess Endowment Holdings in Not-For-Profit Firms, Journal of Accounting and Economics, page 307-333.

Delima, Rosa dan Putriana Kristanti, 2016, Pengembangan Arsitektur Sistem Informasi Keuangan Gereja Kristen Jawa, Jurnal EKSIS, Vol. 09, No. 01, hal. 01-12.

Fama, Eugene F. and Michael C. Jensen, 1983a, Separation of Ownership and Control, Journal of Law and Economics, Vol. 26, No. 2, page 301325. 
Fama, Eugene F. and Michael C. Jensen, 1983b, Agency Problems and Residual Claims, Journal of Law and Economics, Vol. 26, No. 2, page 327-349.

Hofmann, Mary Ann and McSwain Dwayne, 2013, Financial Disclosure Management In The Nonprofit Sector: A Framework for Past and Future Research, Journal of Accounting Literatur, No. 31, page 61-87.

Ikatan Akuntan Indonesia (IAI), 2012, Standar Akuntansi Keuangan Revisi 2009, Salemba Empat, Jakarta.

Kaomaneng, Irena Septianita, 2013, Penerapan Sistem Akuntansi Dalam Pengelolaan Keuangan Gereja, Journal Uniera, Vol. 2, No.1.

Kearns, Kevin P., 2000, Private Sector Strategies for Social Sector Success: The Guide to Strategy and Planning for Public and Non Profit Organizations, : The Jossey-Bass Inc. Publisher, San Fransisco.

Kieso, Donald E., Jerry J. Weygandt and Terry D. Warfield, 2017, Akuntansi Keuangan Menengah, Intermediate Accounting, Edisi IFRS, Volume 1, Penerbit Salemba Empat, Jakarta.

Kitching, 2009, Audit Value and Charitable organizations, Journal of Accounting and Public Policy, Vol. 28, No. 6, page 510-524.

Nainggolan, Pahala, 2012, Manajemen Keuangan Lembaga Nirlaba, Yayasan Bina Integrasi Edukasi, Jakarta.

Schekkerman J., 2009, Enterprise Architecture Good Practices Guide: How to Manage The Enterprise Architecture Practice, IFEAD/TOGAF Open Standards, Diakses dari http://www.enterprise-architecture.info.

Silbiger, Steven, The 10-Day MBA 1998: A Step-By-Step Guide To Mastering The Skills Taught In Top Business Schools,
Judy Piatkus Ltd. of 5 Windmill Stress, London.

Stair, Ralph M. and George W. Reynolds, 2014, Fundamental of Information Systems, Seventh Edition, Course Technology, Boston, USA.

Stenzel, J. (Ed.), 2007, CIO Best Practices, John Wiley \& Sons Inc., Hoboken.

Sutomo, Sumengen, 2007, Manajemen Strategik Organisasi Nirlaba, Jurnal Kesehatan Masyarakat Nasional, Vol. 1, No. 4.

University of Toronto Website, 2015, Introduction to FIS, Diakses dari http://www.finance.utoronto.ca/gtfm/fis /intro.htm pada 25 Februari 2015. 